DOI: 10.18468/letras.2017v7n4.p31-57

\title{
A família nuclear burguesa e a ressignificação do feminino no \\ Brasil do século XIX: um estudo a partir do romance Senhora
}

\author{
Daniele Ribeiro de Faria ${ }^{1}$
}

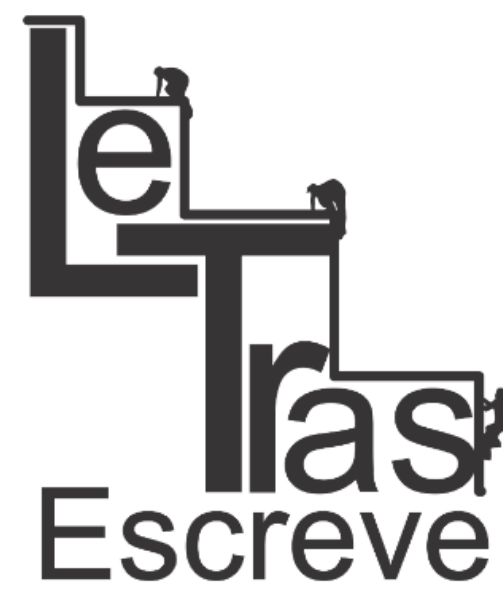

(ISSN 2238-8060)

Resumo: Como parte das transformações sociais, políticas e econômicas ocorridas no século XIX, uma nova configuração familiar passa a vigorar na sociedade, redefinindo principalmente o papel feminino no seio doméstico. E é nesse cenário que o escritor José de Alencar vai escrever, como parte de seu projeto literário, o romance Senhora, cuja personagemprotagonista, Aurélia Camargo, incorporou a figura da heroína romântica, idealizada pelo autor a partir dos padrões sociais vigentes. Tal como a literatura, outros enunciados foram postos em circulação para legitimar a hegemonia dos valores burgueses, além de desencadear uma crescente regulação da sexualidade dos sujeitos, alterando significativamente os costumes da época. Sendo assim, o presente artigo tem como objetivo analisar a representação do feminino presente no romance alencariano, sem deixar de contextualizar as construções discursivas que circulavam na nossa sociedade, bem como as relações de gênero e sexualidade que foram sendo estabelecidas no período considerado.

Palavras-chave: Gênero, Representação, Biopolítica, Romantismo

Abstract: As part of the social, political, and economic transformations that occurred in the nineteenth century, a new family configuration takes effect in society, mainly redefining the feminine role in the domestic domain. And, it is in this scenario that the writer Jose de Alencar writes, as part of his literary project, the novel Senhora, whose character-protagonist, Aurélia Camargo, incorporated the figure of the romantic heroine, idealized by the author from the current social standards. Such as the literature, other statements were put into circulation to legitimize the bourgeois values hegemony, besides triggering a growing regulation of subjects' sexuality, significantly altering the customs of the time. Thus, in the present article has as objective to analyze the feminine representation present in the Alencarian novel, without neglecting to contextualize the discursive constructions that circulated in our society, as well as the relations of gender and sexuality that were being established in the considered period.

Keywords: Gender. Representation. Biopolitics. Romanticism

\footnotetext{
${ }^{1}$ Mestra profissional em Educação pelo Programa de Pós-Graduação em Educação, na área de Gênero e Diversidades na Educação da Universidade Federal de Lavras - UFLA. Atualmente é servidora técnico-administrativa em educação da Universidade Federal de Lavras. Também integra o Grupo de Pesquisa Relações entre Filosofia e Educação para a Sexualidade na contemporaneidade: a problemática da Formação Docente - Fesex, do Departamento de Educação (DED/UFLA).E-mail: daniribeirof.2@gmail.com
}

https://periodicos.unifap.br/index.php/letras

Macapá, v. 7, n. 4, 2 semestre, 2017 


\section{Introdução}

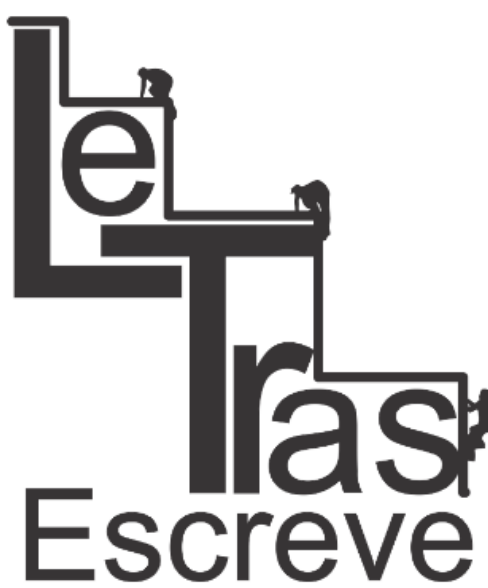

(ISSN 2238-8060)

A sociedade brasileira do Segundo Reinado começa a dar os primeiros sinais de uma lenta transformação em seu modo de organização social e econômica, entre elas, o crescimento e o fortalecimento da classe burguesa e a consolidação do capitalismo. Com essas mudanças, vai ser operado um processo de reinvenção do feminino e a reestruturação da família tradicional.

"Bela, recatada e do $\operatorname{lar}^{\prime 2}$ nos diz muito sobre o ideal da muIher burguesa que vigorou a partir da segunda metade do século XIX e presente também nos romances do período do Romantismo. E não por acaso, essa imagem da mulher ideal, de indubitável beleza (e, diga-se de passagem, a beleza considerada aqui está ancorada nos padrões eurocêntricos), pura, meiga, dócil, entregue à tutela do homem e à maternidade e recolhida ao ambiente privado, faz parte de um modelo de conduta ainda em vigor nos dias de hoje. Esse ideal atribui valores distintos para cada "tipo" de mulher: um valor positivo à mulher que se submete aos códigos de comportamento aceitável, e outro negativo à mulher que não está dentro da norma, aquela que merece ser corrigida e/ou sofrer punições.

Legitimada pelo modo de vida cristão, a família patriarcal brasileira era composta por um grande número de dependentes, agregados/as e escravos/as durante o período colonial. A "casa grande" era gerenciada pela figura do patriarca, geralmente o homem mais velho da casa, que detinha o poder sobre os/as demais. Aos poucos, essa organização familiar foi cedendo lugar à família nuclear burguesa,

\footnotetext{
${ }^{2}$ Termo emprestado de uma reportagem da Revista Veja (publicada em 18/04/2016) com o título Marcela Temer: bela, recatada e 'do lar', de Juliana Linhares, que descreve as "qualidades" e o cotidiano daquela que viria a ser a primeira-dama provisória do Brasil. A matéria causou polêmica nas redes sociais, dividindo opiniões entre o público feminista que rechaçou o texto, e o público mais conservador, que defendeu esse ideal preconizado à mulher brasileira (LINHARES, 2016).
} 


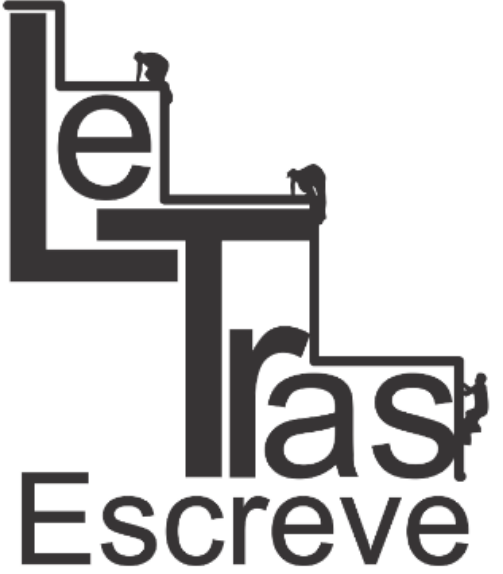

(ISSN 2238-8060) menos numerosa, formada por pai, mãe e filhos/as e, quando um de seus membros assumia o matrimônio, mudava-se para uma residência própria, mais reservada à intimidade de sua nova família.

É dentro desse panorama histórico e social que José Martiniano de Alencar (1829-1877) escrevia seus romances. Cearense e filho de senador, mudara-se ainda menino para o Rio de Janeiro - cidade na qual ele viveu a maior parte de sua vida. Como escritor, é considerado um dos responsáveis por solidificar e amadurecer a prosa romântica brasileira, vindo a ter uma vasta obra consolidada na historiografia literária na fase conhecida como Romantismo, publicando nada menos do que vinte e um romances, os quais são divididos em indianistas, históricos, regionais e urbanos (BOSI, 2006).

Além dos romances, Alencar também teve uma considerável produção jornalística, teatral e jurídica. Seu projeto em vida era o de uma construção (ou seria invenção?) de uma identidade nacional pósindependência, unindo em sua obra ficções ambientadas de norte a sul do país, com personagens que, a seu ver, representavam a formação da cultura e da sociedade brasileira. Alencar reforçava também, e principalmente, a instalação da hegemonia do ideário burguês. É na literatura que residia também a possibilidade de implementar seu projeto pedagógico, apresentando e ensinando a moral burguesa que deveria orientar a conduta feminina, embora a literatura tenha tido um alcance menor devido ao fato de que, na época, somente uma pequena parcela da população era letrada.

2. Controle e regulação da sexualidade feminina: poderes, saberes, verdades

Para que a nova organização social se consolidasse, as institui- 


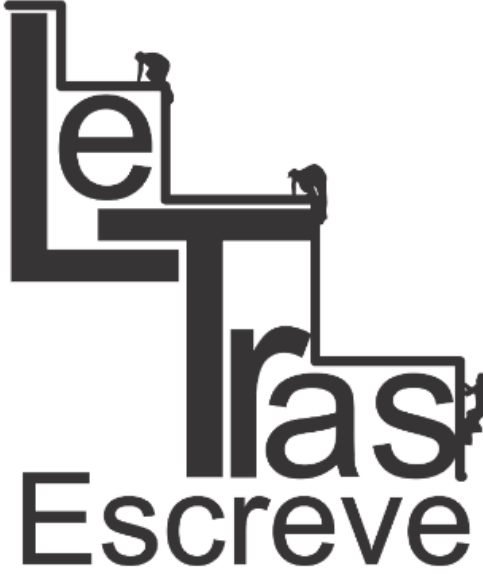

(ISSN 2238-8060)

ções e os processos econômicos produziram, com certa regularidade, os discursos que iriam conduzir, guiar e determinar os padrões de comportamento da época. Com o processo de urbanização, um novo conjunto arquitetônico das cidades vai transformar o cenário brasileiro do Segundo Reinado, em uma tentativa de se assemelhar ao modo de vida europeu, ainda que timidamente.

A construção de moradias burguesas foi reestruturada para conferir uma maior privacidade às famílias que iam se formando. Os espaços da casa demonstravam uma nítida separação entre o público e o privado, as salas serviam para receber visitas ao passo que as alcovas eram o lugar de maior intimidade dos casais. As mães deveriam dar atenção especial no cuidado com os bebês, regras foram disseminadas em como agir ou se comportar, o convívio entre meninos e meninas foi ficando cada vez mais apartado, as habitações também foram sendo arquitetadas para separar adultos de crianças, com quartos que os dividiam.

Configurava-se então um novo quadro de arranjo familiar, onde era dada atenção especial à intimidade, ao prazer, mas também ao poder. Era, pois, uma dupla incitação: poder e prazer. "Prazer em exercer um poder que questiona, fiscaliza, espia, investiga, revela, e por outro lado, escapa a esse poder, foge-Ihe, engana-lhe" (FOUCAULT, 2007, p. 45).

Forja-se a ideia de privacidade, fruto do individualismo burguês, e, como decorrência, revaloriza-se o espaço privado, ao mesmo tempo lugar do "dever", mas também do "prazer". É nesse espaço que se opera a afirmação da família tipicamente burguesa, com suas noções de intimidade. (GONÇALVES, 2006, p. 39)

Ao mesmo tempo em que houve uma reorganização dos espa-

https://periodicos.unifap.br/index.php/letras

Macapá, v. 7, n. 4, 20 semestre, 2017 


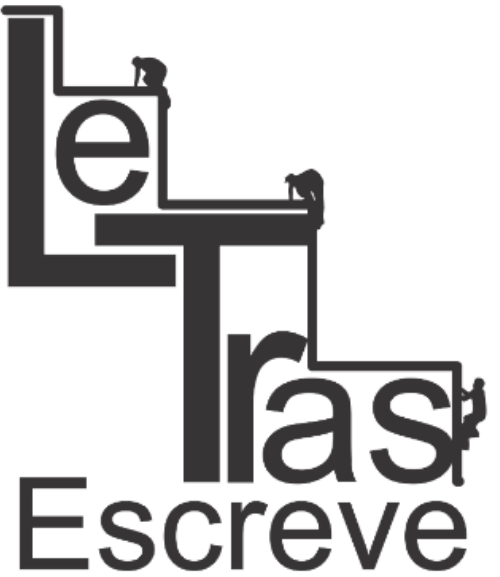

(ISSN 2238-8060)

ços público e privado, uma mudança passa a operar em direção a uma ressignificação do papel da mulher na sociedade. Se antes o lar era regido pelo patriarca da família, agora a mulher passa a ter uma posição central no ambiente doméstico, responsável pelos cuidados da casa e dos membros da família. A mulher burguesa do final do século XIX passou a ser considerada a "rainha do lar" e, para isso, todos os esforços foram investidos para que a mulher fosse educada de maneira a tornar-se um modelo ideal de feminilidade. São as representações da mulher puritana, virtuosa, compassiva e extremamente devotada ao lar, o que a tornava também dessexualizada, desprovida de qualquer sinal que manifestasse algum desejo no e do corpo.

Os códigos que regiam as práticas sexuais vão ter como foco principal as relações matrimoniais: o sexo dos cônjuges passou a ser submetido a uma série de regras e condutas, além de uma pesada vigilância. O casal legítimo era aquele que estava em consonância com o padrão monogâmico-heterossexista. Aquilo que fugia dessa legitimidade deveria ser investigado e corrigido.

Para Foucault (2007), a história da sexualidade está diretamente condicionada às relações de poder que vão constituir os saberes acerca do sexo. Em outras palavras, tudo o que se sabe sobre o sexo deriva do saber constituído pelos mecanismos de poder, ou seja, toda a construção do discurso sobre a sexualidade que circulou na nossa sociedade está atravessada por essas relações. São os saberes científicos, médicos, pedagógicos, filosóficos que, inseridos em um contexto histórico e social específicos, vão ditar o que é padrão, o verdadeiro, a norma, o legítimo.

Embora alguns discursos tenham sido removidos da circulação social, não se trata necessariamente de uma repressão desses discursos, mas sim de determinar quem e onde se pode falar sobre o sexo,

https://periodicos.unifap.br/index.php/letras

Macapá, v. 7, n. 4, 2을 semestre, 2017 


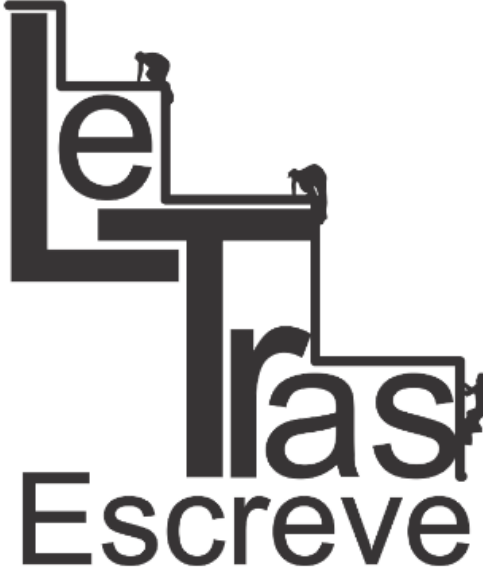

(ISSN 2238-8060)

devendo passar primeiramente pelo crivo da família, da igreja, do Estado e da própria ciência. Indo na contramão de grande parte dos estudiosos que acreditavam na "hipótese repressiva" do período vitoriano, Foucault (2007) nos mostra em como os discursos acerca do sexo foram constantemente incitados pelas diversas instituições, movidas por uma vontade de saber.

O que se pode concluir é que a sociedade investiu todo um aparelho de incitação ao discurso sobre o sexo. Como diz Foucault (2007, p. 34), "o sexo se tornou algo que se deve dizer exaustivamente, segundo dispositivos diversos, mas todos constrangedores". Era preciso, pois, que se falasse do sexo para então poder melhor desvendá-lo, examiná-lo, definir quem pode falar e onde se pode falar sobre o sexo. No lugar das interdições, das repressões, dos silenciamentos, o que se pode perceber é uma incitação institucional e uma multiplicação dos discursos sobre o sexo: falar mais e de forma mais detalhada. A partir do século XIX, os discursos científicos sobre ele vão ganhar mais impulso.

A procura pela verdade do sexo propiciou a formação de muitos conceitos, teorias, normas, bem como o controle e a regulação cada vez mais sofisticada dos sujeitos. Para isso, foi constituída uma grande aparelhagem para produzir os discursos. Serão os confessionários, as salas de aulas, os cômodos privativos da casa e os consultórios médicos os grandes "ouvidos" para os dizeres sobre o sexo. Como afirma Foucault (2007, p. 24), era preciso, pois, "não somente confessar os atos contrários à lei, mas procurar fazer do seu desejo um discurso".

A medicina, a psiquiatria, a justiça penal e demais instituições vão trabalhar para criar, nomear e classificar uma série de sexualidades: a da criança, da mulher, do homossexual, do louco. O campo da

https://periodicos.unifap.br/index.php/letras

Macapá, v. 7, n. 4, 20 semestre, 2017 
sexualidade, segundo Foucault (2007, p. 78), passa a ser "um domínio penetrável por processos patológicos, solicitando, portanto, intervenções terapêuticas ou de normalização". No caso das sexualidades femininas, foi trabalhado nos discursos médicos e científicos um novo modelo normativo de feminilidade, bem como sua patologização. Segundo relata Foucault (2007, p. 115), a histerização, por exemplo, foi um

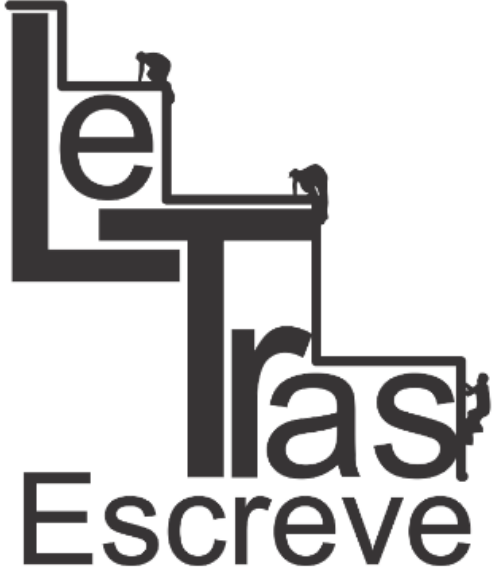

(ISSN 2238-8060)
Tríplice processo pelo qual o corpo da mulher foi analisado - qualificado e desqualificado - como corpo integralmente saturado de sexualidade; pelo qual, este corpo foi integrado, sob o efeito de uma patologia que lhe seria intrínseca, ao campo das práticas médicas; pelo qual, enfim, foi posto em comunicação orgânica com o corpo social (cuja fecundidade regulada deve assegurar), com o espaço familiar (do qual deve ser elemento substancial e funcional), e com a vida das crianças (que produz e deve garantir, através de uma responsabilidade biológico-moral que dura todo o período da educação): a Mãe, com sua imagem em negativo que é a "muIher nervosa", constitui a forma mais visível desta histerização.

Percebe-se aí como diversos mecanismos de controle foram desenvolvidos para normatizar o comportamento sexual das mulheres. A histerização do corpo feminino vem se configurar como um dos dispositivos normatizadores e normalizadores para assegurar o seu "equilíbrio". A mulher deveria seguir a sua "vocação natural", dedicando-se ao casamento e à maternidade. O sexo deveria ter como fim único a procriação. Qualquer sinal de desvio dentro dessa normalidade poderia resultar em algumas crises nervosas e instabilidade emocional, consideradas sintomas da histeria.

Em História da Sexualidade 1 - a vontade de saber, Foucault (2007, p. 151) aponta que o poder sobre a vida desenvolveu-se em 


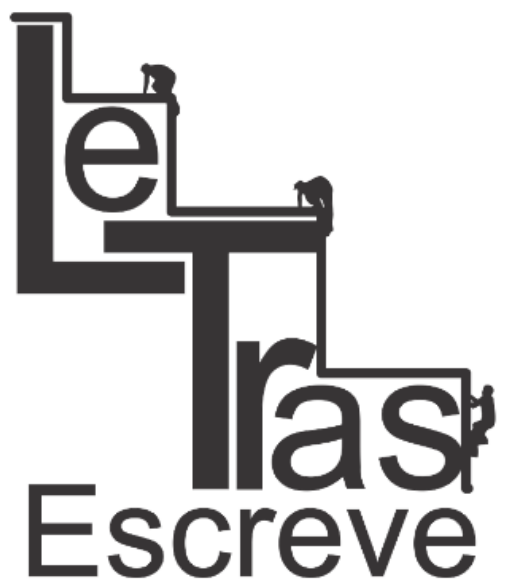

(ISSN 2238-8060)

duas direções principais: primeiro, com as disciplinas, centrando-se no corpo-máquina a fim de torná-lo útil e dócil, e segundo, um pouco mais tarde, o poder centrou-se no corpo-espécie, ou seja, desenvolveu-se uma biopolítica da "população", que visava a obter a sujeição dos corpos e a inserção controlada destes no "aparelho de produção e por meio de um ajustamento dos fenômenos de população aos processos econômicos" (FOUCAULT, 2007, p. 153). A preocupação com as taxas demográficas, a longevidade da população, enfim, tudo o que diz respeito aos fenômenos biológicos do corpo vivo, configurase como formas de agenciamento e controle do corpo social, necessárias para o desenvolvimento do capitalismo. 0 dispositivo da sexualidade, para Foucault, será a mais importante tecnologia de poder no século XIX.

O que se passa nas alcovas é objeto de interesse, como mostraram em primeiro lugar os historiadores franceses: dão conta de uma profusão de manuais elaborados pelos médicos, que orientam sobre a melhor forma de gerar filhos saudáveis. A duração do coito, posições sexuais, dispêndio de sêmen uma profusão de detalhes até então escondidos na marginal literatura erótica passa a integrar os discursos da "ciência". (BOCAYUVA, 2007, p. 29)

Foucault (2007, p. 153) destaca ainda a atuação de grandes aparelhos do Estado que vão agir no desenvolvimento das políticas públicas de saúde, definindo as "doenças da sociedade" e a necessária higienização dos espaços urbanos como medidas profiláticas, fazendo com que o "biopoder" esteja presente em todos os níveis do corpo social. Em outras palavras, as "técnicas de poder" vão operar de forma articulada com as diversas instituições (a família, a escola, a medicina, o quartel, a fábrica) para regular a vida da população como um todo.

https://periodicos.unifap.br/index.php/letras

Macapá, v. 7, n. 4, 20 semestre, 2017 
O cenário brasileiro do final do século XIX apresenta alguns desafios e impasses para a implantação da biopolítica. Vale ressaltar que, apesar das mudanças observadas já no final do período colonial, a tradição patriarcal ainda se arrastou por um bom tempo, tendo em vista que a sociedade brasileira ainda era predominantemente rural e agrária, cuja economia dependia da exportação de bens de consumo e produtos agrícolas. De acordo com Bocayuva (2007), somente a partir da década de 1930 do século XX houve um crescimento significativo dos centros urbanos, contrapondo-se, de certa forma, à economia latifundiária das oligarquias rurais.

Com isso, a biopolítica no Brasil será implantada tardiamente

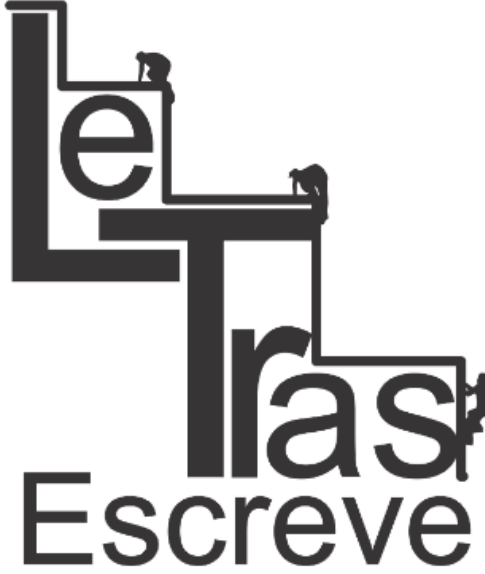

(ISSN 2238-8060) devido à longa tradição patriarcal e escravagista ancorada no poder soberano que se estendeu até o final do século XIX, constituindo um obstáculo para a modernização da sociedade brasileira (BOCAYUVA, 2007). No entanto, conforme já observado, a introdução dos valores europeus na sociedade fez-se presente já no período do Brasil Império e, depois, com a urbanização do país, esta com mais densidade no início do século XX. O que se observa nesse período é uma crescente regulação da sexualidade da população, alterando significativamente os costumes da época.

De acordo com Miskolci (2013, p. 25):

O Estado brasileiro em sua forma republicana inicial encontrou na nação o eixo justificador que conectava os interesses da elite política e econômica ao progressivo controle das classes populares, mas fato a ser melhor explorado - isto se deu não apenas pelas amplamente estudadas intervenções higienistas no espaço urbano, mas também por meio de formas mais sutis de interferência e disciplinamento das relações íntimas, dentro do ideal de vida privada e doméstica, em especial na esfera das relações de gênero e da sexualidade.

https://periodicos.unifap.br/index.php/letras

Macapá, v. 7, n. 4, 20 semestre, 2017 
O matrimônio e a maternidade passaram a ser fundamentais para que os interesses privados da família burguesa fossem assegurados, como a transmissão da herança, o prestígio político e social na esfera pública e o enriquecimento através de transações familiares por meio do dote adquirido da família da noiva.

Importante lembrar que, entre as classes mais abastadas, a virgindade era um requisito indispensável para a consumação do casamento e, por essa razão, a mulher deveria manter-se "pura" e intocável até o momento de ser desposada.

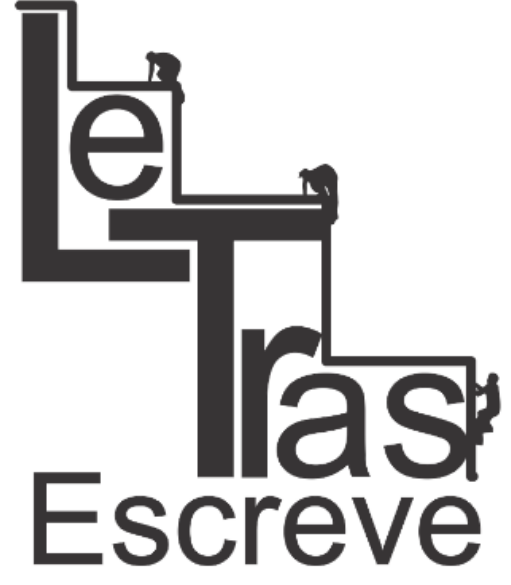

(ISSN 2238-8060)
Em outras palavras, nos casamentos das classes altas, a respeito dos quais temos documentos e informações, a virgindade feminina era um requisito fundamental. Independentemente de ter sido ou não praticada como um valor ético propriamente dito, a virgindade funcionava como um dispositivo para manter o status da noiva como objeto de valor econômico e político, sobre o qual se assentaria o sistema de herança de propriedade que garantia linhagem da parentela. (INCAO, 2015, p. 235)

Nessa época, com a ascensão da classe burguesa, cresce também a formação de um público leitor que buscava na literatura histórias sentimentais e familiares que se aproximavam dos padrões da classe burguesa. Antes dos romances tomarem a forma da prosa como a conhecemos hoje, as histórias eram contadas através de folhetins, cujas publicações se davam por capítulos, diariamente, nos jornais que circulavam na época. Os romances folhetinescos utilizavam uma linguagem mais simples e direta, narrando a vida cotidiana das pessoas e os acontecimentos mais banais. Muitos desses romances que obtinham sucesso de público eram publicados posteriormente em formato de livros.

Mesmo com o crescimento de um público leitor, Luis Ribeiro 
(2008) nos lembra de que o consumo dos bens culturais era um privilégio de poucos. A literatura constituía-se na mais legítima forma de expressão da classe burguesa, ou seja, de uma minoria privilegiada. Outro dado interessante que merece ser destacado é que o público leitor era composto majoritariamente por mulheres, mesmo sendo escrito exclusivamente por homens.

O público leitor, por excelência, era o feminino. Primeiro porque o romance - como a literatura, de modo geral - encontra seu espaço, em nossa sociedade aristocrática e iletrada, no lazer das mulheres das classes altas. Os homens estão voltados para seus negócios; as mulheres, ociosas, precisam encontrar formas de preencher seu tempo, já que o trabalho doméstico está a cargo das escravas, que não entram na história... (RIBEIRO, 2008, p. 50)

Ribeiro (2008, p. 50) ainda conclui que "o romance do século XIX é escrito por homens, sobre mulheres e dirigido às mulheres". A literatura dessa época serviu para incutir na população os valores burgueses e, portanto, ela funcionava como uma pedagogia cultural cujo objetivo era ensinar às mulheres o seu devido lugar.

\section{Senhora: a idealização da mulher burguesa no imaginário brasi-} leiro

O romance Senhora (1875) integra a série "perfis femininos" escrita por José de Alencar, juntamente com Lucíola (1862) e Diva (1864). Por ser um dos últimos romances que Alencar escrevera, Senhora vem apresentar um enredo dotado de maior maturidade em relação aos anteriores.

No romance em questão, o casamento como meio de ascensão social aparece como uma espécie de fio condutor que liga as perso- 


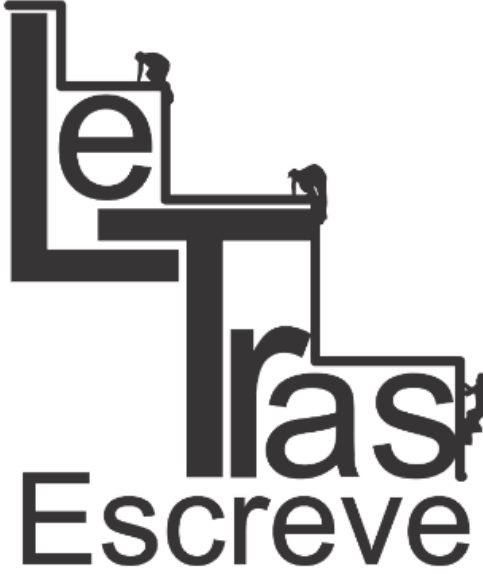

(ISSN 2238-8060) nagens e escancara a realidade social do Brasil pós-colonial e, a partir dessa condução, o autor passa a denunciar o mercado matrimonial vigente na época, dentro do qual as relações humanas e afetivas foram sendo estabelecidas. Embora o enredo seja construído com um viés realista, Alencar não abandona a veia romântica que tece toda a trama, atingindo seu ápice no desfecho do livro, conforme veremos adiante.

A protagonista do romance é Aurélia Camargo, uma moça pobre e órfã de pai, moradora do bairro de Santa Teresa junto com sua mãe e seu irmão mais velho. Ainda na mocidade, Aurélia vê seu irmão falecer e a saúde da mãe se agravar e, com isso, surgem as pressões por parte da mãe para que a moça arranje um marido, uma vez que a sociedade não via com bons olhos uma mulher sem a tutela de um homem, emancipada socialmente. É aí que Fernando Seixas entra em cena, ao avistar a bela jovem que se demorava na janela durante as tardes de Santa Teresa.

Inicia-se a partir daí um namoro entre os dois, mas sempre com a estreita vigilância da mãe. Seixas, apesar de ser descrito como um bom rapaz e ter se apaixonado verdadeiramente por Aurélia, não é capaz de abandonar suas aspirações pessoais e, por essa razão, troca-a por outra moça pouco tempo depois, já que a pobre Aurélia nada tinha a oferecer a ele em termos de status social e bens materiais. A grande reviravolta da história dá-se quando Aurélia descobre que é a herdeira universal dos bens do avô paterno, um fazendeiro com grandes terras de inestimável valor.

Tendo perdido a mãe pouco tempo depois de receber a herança, Aurélia passou a contar apenas com a companhia da viúva D. Firmina Mascarenhas, uma velha parenta que se passava por uma espécie de mãe de encomenda. A jovem, agora com dezoito anos, aparece

https://periodicos.unifap.br/index.php/letras

Macapá, v. 7, n. 4, 2을 semestre, 2017 


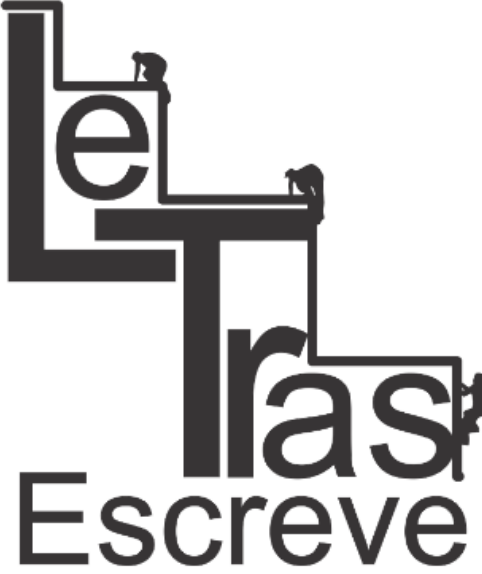

(ISSN 2238-8060) pela primeira vez na alta sociedade fluminense como uma "nova estrela". Considerada uma das mais belas e formosas do Rio de Janeiro, Aurélia passou a ser cortejada por inúmeros pretendentes. Era a "rainha dos salões", a "deusa dos bailes", a "musa dos poetas" (ALENCAR, 2010, p. 15).

Mas nem por isso ela esqueceu-se do noivo por quem fora abandonada por um dote de melhor valor e, para vingar-se, decide comprá-lo por um dote de cem contos de réis - na época uma verdadeira fortuna - sem que sua identidade fosse revelada até que o contrato fosse feito. Diante dessa proposta mais do que tentadora, Seixas aceita sem mesmo saber a verdadeira identidade de sua noiva e desfaz-se do compromisso assumido com Adelaide Amaral.

É aí que tem início o imbróglio que vai se arrastar durante todo o enredo. O livro é dividido em quatro partes: $O$ preço, que vai contar como se deu a contratação do noivo por Aurélia; Quitação, quebrando a linearidade da narrativa quando faz um retorno ao passado de Aurélia e às suas origens; Posse, que relata o convívio do casal diante dessa situação infortunada de ambos e, por último, Resgate, quando Seixas finalmente consegue devolver à esposa a quantia que recebera durante o contrato matrimonial, reconquistando sua liberdade. Cada uma dessas partes está subdivida em vários capítulos.

Logo no primeiro capítulo, o autor narra a primeira aparição de Aurélia na Corte:

Há anos raiou no céu fluminense uma nova estrela. Desde o momento de sua ascensão, ninguém lhe disputou o cetro; foi proclamada a rainha dos salões.

Tornou-se a deusa dos bailes; a musa dos poetas e o ídolo dos noivos em disponibilidade.

Era rica e formosa.

Duas opulências, que se realçam como a flor em va- 
so de alabastro; dois esplendores que se refletem, como o raio de sol no prisma do diamante.

Quem não se recorda da Aurélia Camargo, que atravessou o firmamento da corte como brilhante meteoro, e apagou-se de repente no meio do deslumbramento que produzira o seu fulgor? (ALENCAR, 2010, p. 15).

Uma das características da linguagem romântica é a idealização de suas personagens mediante um recorte subjetivo de como o autor masculino as vê. A mulher é sempre vista como algo puro, inatingível, desencarnada e, para isso, o narrador utiliza-se de ampla metaforização para descrever minuciosamente suas heroínas. No trecho acima, há uso recorrente de matérias frias e resistentes, como os minerais preciosos: "flor em vaso de alabastro", "raio de sol no prisma do diamante", uma clara alusão à beleza e à riqueza da moça. No decorrer do livro, ainda observamos outras comparações com objetos frios e duros, que conotam perfeição, imobilidade e delicadeza, como quem diz que aquilo não pode ser tocado: "lábios de nácar", "estátua de cera" (ALENCAR, 2010, p. 22), “estátua de mármore” (ALENCAR, 2010, p. 56), além, é claro, de elevá-la ao posto de realeza, de deusa, soberana aos demais, ao empregar palavras como "rainha", "musa", "deusa". Porém, a heroína aparece não como uma figura de autoridade, e sim como objeto que deve ser contemplado, disputado, conforme demonstra a frase assinalada pelo narrador: "Assaltada por uma turba de pretendentes que a disputavam como o prêmio da vitória" (ALENCAR, 2010, p. 16).

Importante frisar que as transações no mercado matrimonial davam-se entre homens. Segundo nos conta Ribeiro (2008), as muIheres tinham um papel pequeno na negociação ou, muitas vezes, sequer ficavam sabendo. A negociação ficava sob encargo do pai da noiva e, nas palavras de Ribeiro (2008, p. 151), “a noiva só entra na 


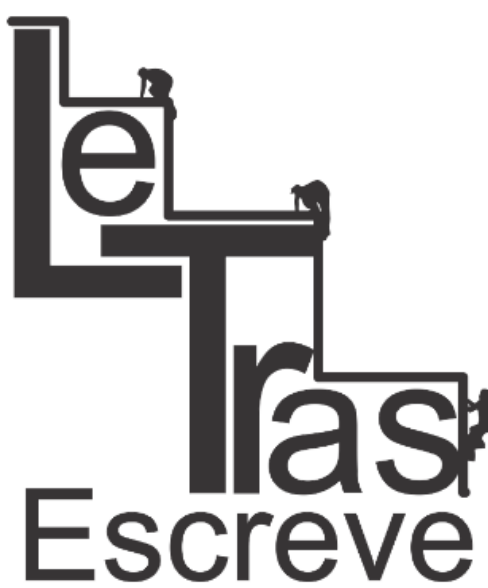

(ISSN 2238-8060)

história depois de selado o contrato e como o objeto material da transação".

No entanto, na ficção, sabemos que Aurélia contava apenas com a companhia de outra mulher, D. Firmina, o que a impedia de negociar seu próprio casamento, mesmo dominando toda a linguagem financeira desse mercado e administrando seus próprios bens, faculdades estas consideradas masculinas.

Para fazer a encomenda do noivo e preservar sua identidade, Aurélia, como órfã, teve de recorrer ao seu parente masculino mais próximo, o Sr. Lemos. Mas a escolha do noivo, os termos e condições da proposta, a forma e a quantia do pagamento, tudo foi decidido por ela. Ao tio Lemos, coube apenas a tarefa de contatar Seixas e oferecer-lhe a proposta. O que demonstra que Aurélia sabia bem o que queria e não precisava da tutela ou conselho de nenhum homem para, nas palavras dela, comprar a sua felicidade.

Mercado, compra, transação, cotação, troca, dinheiro. Todas essas palavras associadas à linguagem financeira formam o ingrediente do casamento nada romântico de Aurélia e Seixas. Diferente das histórias de amor e heroínas românticas predominantes no Romantismo, o casamento aparece na narrativa como melhor meio de aquisição econômica e ascensão social. Nesse contexto, a mulher era vista como produto, como bem a ser adquirido. Em uma fala de Aurélia, ela desabafa: "a moça rica é um arranjo, e não uma esposa" (ALENCAR, 2010, p. 121). Com essa passagem mostrada no texto, José de Alencar pretende deixar exposta com sua crítica a "empresa nupcial" que vigorava na sociedade, por meio da qual as pessoas se moviam de acordo com seus interesses. O casamento burguês apresentava-se então como a solução mais viável (e rentável) para obter prestígio no meio social. 
Para que essa ideia de casamento fosse aceita sem grandes oposições, houve todo um investimento social para reforçar a ideia do amor familiar. De acordo com Incao (2015), a emergência da família burguesa fez com que o papel do feminino fosse redefinido. E aí, como já vimos anteriormente, a mulher passa a ser educada para o casamento, para o lar, para o cuidado com os/as filhos/as e o marido.

Embora Aurélia possa parecer, em um primeiro momento, a frente do seu tempo, mostrando-se uma mulher independente e capaz de controlar e administrar sua riqueza - por isso o título Senhora - é evidente a importância que ela dá ao casamento, como o objetivo último que deve ser na vida de toda mulher: casar e constituir uma família. Sabe-se que no século XIX, as mulheres casavam-se muito cedo. Aurélia já contava com 19 anos quando decidiu se casar. Segundo Ribeiro (2008), as mulheres casadoiras tinham entre 14 e 18 anos, quando muito, 20. Se com 21 anos, a mulher ainda não tinha contraído o matrimônio, tinha grandes chances de ficar para o celibato.

Já foi visto também como diversos mecanismos foram criados para impelir a mulher para dentro do lar e seguir o seu curso "natu(ISSN 2238-8060) ral", que é o de ser mãe e esposa. Não conseguir um casamento era carregar consigo o peso da estigmatização social, da figura abjeta, antinatural. Alencar (2010, p. 43) não hesita em comparar, por exemplo, a solteirice com "aleijão social", ou seja, para ele, em consonância com as verdades sancionadas na época, a solteirice era considerada uma deformidade, uma mutilação da natureza feminina, uma aberração.

Findada a cerimônia de casamento restrita a uns poucos convidados, é chegado o momento de Aurélia e Seixas ficarem a sós, enfim casados. Porém, ao contrário do que acontece nos romances ro- 
mânticos, o mais novo casal não se vê envolto em um "mar de rosas". Aurélia finalmente abre o jogo sobre suas verdadeiras intenções, surpreendendo Fernando e deixando-o em uma situação um tanto quanto desconfortável e humilhante. É o que se pode observar no trecho que se segue, parte do diálogo que se estabeleceu entre os dois:

- Representamos uma comédia, na qual ambos desempenhamos o nosso papel com perícia consumada. Podemos ter esse orgulho, que os nossos melhores atores não nos excederiam. Mas é tempo de pôr termo a esta cruel mistificação, com que nos estamos escarnecendo mutuamente, senhor. Entremos na realidade por mais triste que ela seja; e resignese cada um ao que é, eu, uma mulher traída; o senhor, um homem vendido.

- Vendido! exclamou Seixas ferido dentro d'alma.

- Vendido sim: não tem outro nome. Sou rica, muito rica, sou milionária; precisava de um marido, traste indispensável às mulheres honestas. O senhor estava no mercado, comprei-o (ALENCAR, 2010, p. 8081, grifo nosso).

Encerra-se então a primeira parte do livro. Temos diante de nós a figura de uma mulher resoluta, impiedosa, sedenta por devolver a Seixas toda a humilhação que ela guardava consigo ao ser aban(ISSN 2238-8060) donada por um dote de 30 contos de réis. Aqui não se vê a representação de uma mulher frágil e submissa, mas sim aquela que se apodera do "seu" marido - pronome possessivo - ou ainda, seu escravo, o qual ela compra. É Seixas quem vai obedecer as suas ordens, é ele quem se encontra em uma posição inferior, sentado diante de sua Senhora (com S maiúsculo). Ora, cabe lembrar que as relações de poder não são fixas, elas transitam, criam possibilidades de transgressão, de espaços de resistências, de outras relações de poder.

Aurélia não esconde também o seu desprezo pelo mercado matrimonial, o que deixa explícito em sua fala quando ela reafirma 


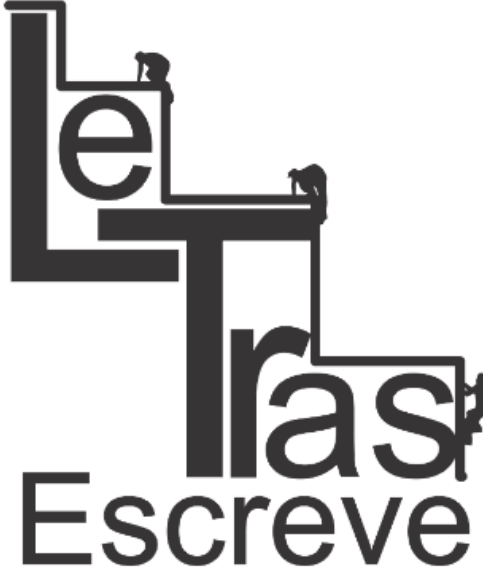

(ISSN 2238-8060) que seu marido foi vendido, atendendo assim a sua posição na sociedade, já que, para uma mulher preservar sua reputação, não era preciso nada mais do que um casamento de conveniência. No caso de Aurélia, a necessidade fez-se ainda mais premente por ser ela, desde cedo, órfã e sozinha no mundo, tendo que aprender com a vida as dificuldades que a sua posição feminina Ihe trazia.

Aurélia, diferente de muitas heroínas românticas, não era uma moça ingênua e não fora criada no mais fino berço da alta sociedade. Tendo experimentado dois mundos de realidade bastante distinta, Aurélia conhecia bem as mazelas e as crueldades de cada um deles e teve que aprender, desde cedo, a se defender e a honrar sua imagem como "moça de respeito", sendo preciso para isso construir uma nova família. E não quis outro noivo senão aquele que a abandonara por outra mulher. Estaria ela ciente da infelicidade que a acompanharia por toda sua vida ou existia nela a esperança de regenerar esse amor que foi contaminado pelo mais vil interesse?

A narrativa segue com constantes tensões entre Aurélia e Seixas. Na terceira parte do livro, denominado Posse, o autor se empenha em apresentar ao público leitor a intimidade do lar, que se resume à difícil convivência entre o casal e a tentativa de disfarçar esse infortúnio perante a sociedade e também as pessoas mais próximas depois daquele episódio infeliz.

Aurélia, não raras vezes se esforçava para parecer senhora de si, determinada e confiante, a esbanjar alegria pela casa, ao passo que Fernando não escondia sua condição de servo que estava ali para satisfazer as vontades de sua esposa e o fazia justamente para irritar Aurélia. Embora a heroína possa ser apresentada com um perfil feminino a frente do seu tempo, as consequências da sua não-adequação ao papel esperado por cada mulher começam a aparecer, apontando

https://periodicos.unifap.br/index.php/letras

Macapá, v. 7, n. 4, 2o semestre, 2017 
indícios da histerização do corpo feminino: a heroína sofre de alguns desmaios, tem variações na sua temperatura corporal, aparenta estar pálida e com a saúde frágil, vindo a levantar suspeita de que estaria sendo acometida de alguma moléstia. Em uma das passagens do romance, o narrador comenta:

Sucedem-se no procedimento em Aurélia atos inexplicáveis e tão contraditórios, que derrotam a perspicácia do mais profundo fisiologista.

Convencido de que também o coração tem uma lógica, embora diferente da que rege o espírito, bem desejara o narrador deste episodio perscrutar a razão dos singulares movimentos que se produzem n'alma de Aurélia.

Como porém não foi dotado com a lucidez precisa para o estudo dos fenômenos psicológicos, limita-se a referir o que sabe, deixando à sagacidade de cada um atinar com a verdadeira causa de impulsos tão encontrados (ALENCAR, 2010, p. 167, grifo nosso).

Aqui, evidencia-se que o discurso médico aparece na narrativa de Alencar para reforçar a "vocação natural" da mulher. No trecho, Aurélia aparece como imprevisível, indecifrável, inconstante, e a "verdadeira causa" desses "atos inexplicáveis e contraditórios" aparece aos leitores como sendo óbvia: Aurélia vive a contrariar a sua própria "natureza". Como mulher, ela não corresponde aos atributos da esposa ideal, não porque não quer, mas porque está impedida. Em outra passagem da narrativa, D. Firmina sugere que Aurélia tenha um bebê, pois só assim ela poderia melhorar desses males constantes, o que vem a reforçar a exaltação da maternidade como constituinte da natureza feminina. De acordo com Rago (1997, p. 78), “o discurso masculino e moralizador dos médicos e sanitaristas procura persuadir 'cientificamente' a mulher, tanto da classe alta como das camadas baixas, de sua tarefa natural de criação e de educação dos filhos". A 


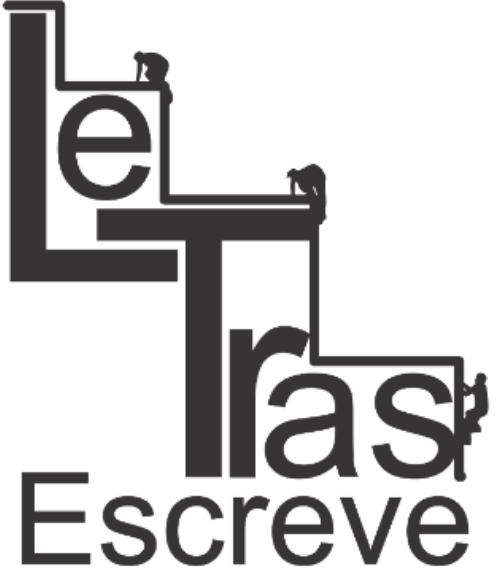

(ISSN 2238-8060)

mulher era preciso, pois, ser mãe e esposa exemplar para preservar a família nuclear moderna que se assentava na sociedade burguesa do século XIX.

E qual o lugar da sexualidade na trama narrativa? O que seriam esses "impulsos tão encontrados"? Estaria o autor insinuando desejos reprimidos de Aurélia? O lugar da sexualidade seria o do interdito, do qual não se pode falar? Como sabemos, o casal não se permitia o envolvimento íntimo entre eles por razões de ordem moral, mesmo que ambos nutrissem um forte sentimento um pelo outro. Desde o primeiro dia após o casamento, Aurélia cuidou para que ambos dormissem em aposentos separados. Como em toda prosa romântica, a muIher era uma figura idealizada, inalcançável, divinizada e, como tal, Aurélia não poderia entregar-se ao desejo sexual diante de um matrimônio contraído através do esquema mercantil, pois, dessa forma, não era o amor em sua forma pura e sim sua renúncia a ele. Ou seja, o sexo para a mulher só poderia ser feito por amor em uma relação legítima e, para isso, cabia à mulher preservar a sua castidade.

Contudo, a não-realização do amor em sua plenitude era prejudicial à mulher, daí os constantes ataques febris dos quais Aurélia vinha sofrendo. Na quarta e última parte do livro, Resgate, há uma aproximação entre o casal e, com isso, sentimentos eróticos são aflorados, mas em situações descritas pelo próprio narrador, uma vez que não era possível que as personagens expressassem seus desejos abertamente um para o outro, pois falar da intimidade sexual estava no campo do interdito.

O ápice desse momento sensual entre o casal acontece quando Aurélia e Seixas se entregam à valsa, depois de certa relutância. Alencar (2010, p. 204) assim expõe os "perigos" da dança:

https://periodicos.unifap.br/index.php/letras

Macapá, v. 7, n. 4, 20 semestre, 2017 
Esse enlevo inocente da dança, entrega a mulher palpitante, inebriada, às tentações do cavalheiro, delicado embora, mas homem, que ela sem querer está provocando com o casto requebro de seu talhe e traspassando com as tépidas emanações de seu corpo (ALENCAR, 2010, p. 204, grifo nosso).

Ou seja, por mais que o homem tenha boas intenções para com a moça, há de se reforçar que os discursos legitimados naquela época concebiam a libido masculina como naturalmente mais pulsante, difícil de ser controlada. Sua "natureza" está mais voltada para o prazer sexual, ao passo que a mulher tem o poder de despertar isso no homem, por isso todo cuidado é pouco. De acordo com os códigos de conduta, é dever da mulher se resguardar e manter-se discreta. E Aurélia parece entender bem disso quando, ao dançarem a valsa, ela não permite que os corpos se toquem, mantendo uma distância entre eles. E esse movimento entre desejos, tentações e autocontrole continuava, vibrante, assim como o soar da música que não cessa com seu ritmo alucinante.

A narração que se segue leva o público leitor a sentir a palpitação ardente do casal, enleados com toda essa volúpia de corpos a bailar. A dança só termina quando, como num relance, os lábios de ambos se tocam e Aurélia novamente tem um desmaio. Diante disso, o narrador novamente vem nos dizer que os excessos não fazem bem a uma mulher, o que nos remete à construção do corpo histérico feminino a qual apontara Foucault (2007).

O final do romance caminha para a redenção de Seixas. Durante todos esses meses, ele poupara cada centavo que recebia com seu ofício e, para a sua sorte e surpresa, ele recebe a notícia de que teria direito a uma parte de um privilégio que lhe daria um lucro de quinze contos. Esse negócio era referente a uma concessão que ele fizera há um tempo, para exploração de umas minas de cobre. Com essa quan- 


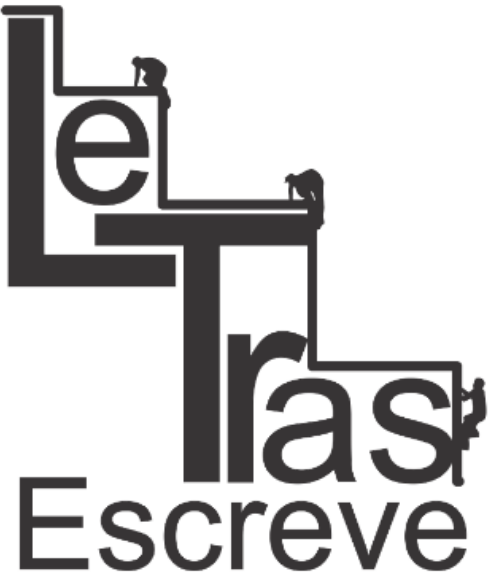

(ISSN 2238-8060)

tia obtida mais o dinheiro que ele tinha poupado, daria para restituir à Aurélia todo o valor do dote que ele recebera durante a transação matrimonial. Seria a chance de finalmente recuperar sua liberdade e sua dignidade, era o seu resgate, sua "carta de alforria". Com isso, não havia mais nada que prendesse Seixas a esse contrato matrimonial, e então ele decide comunicar a Aurélia sobre o resgate de sua liberdade.

É aí que o romance assume a sua veia romântica por definitivo. Não há mais impedimento para que ambos se entreguem ao amor, outrora ultrajado. Seixas, ao devolver todo o dinheiro, estava regenerado, livre para honrar o seu sentimento, da mesma forma em que ele prezou seu compromisso como esposo comprado. E então, antes dele partir, Aurélia o detém, em suplício:

\footnotetext{
- Pois bem, agora ajoelho-me a teus pés, Fernando, e suplico-te que aceites meu amor, este amor que nunca deixou de ser teu, ainda quando mais cruelmente ofendia-te.

A moça travara das mãos de Seixas e o levara arrebatadamente ao mesmo lugar onde cerca de um ano antes ela infligira ao mancebo ajoelhado a seus pés, cruel afronta.

- Aquela que te humilhou, aqui a tens abatida, no mesmo lugar onde ultrajou-te, nas iras de sua paixão. Aqui a tens implorando seu perdão e feliz porque te adora, como o senhor de sua alma (ALENCAR, 2010, p. 236).
}

Tem-se aqui, no último capítulo, o trecho mais emblemático de toda a narrativa. Há uma inversão de posição do homem e da mulher, ou melhor, o recobramento do lugar que deveria pertencer ao homem e à mulher. Agora é Seixas quem se encontra em uma posição superior, ao passo que é Aurélia quem se ajoelha a seu senhor. Durante toda a convivência entre o casal, da posse até o resgate, Seixas

https://periodicos.unifap.br/index.php/letras

Macapá, v. 7, n. 4, 20 semestre, 2017 


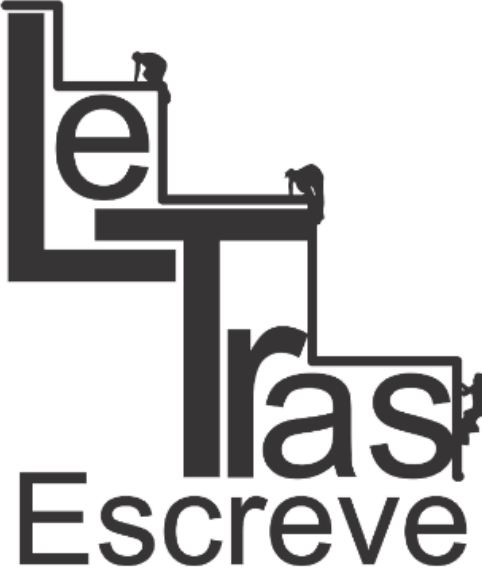

(ISSN 2238-8060)

tivera sua posição de domínio alienada através do contrato de casamento, mas agora, tendo liquidado sua dívida, reintegrara-se por completo. O Resgate é então muito mais do que a regeneração de Seixas. É, sobretudo, a retomada da "legítima" posição a qual pertencem os papeis sociais de gênero no interior da família nuclear burguesa e também patriarcal.

E o desfecho da história não poderia ser mais previsível do que o enlace amoroso do casal: "As cortinas cerraram-se, e as auras da noite, acariciando o seio das flores, cantavam o hino misterioso do santo amor conjugal" (ALENCAR, 2010, p. 236). Enfim sós, enfim livres para amar. Mas tal intimidade não poderia ser escancarada para o/a leitor/a. Utilizando-se de prosopopeias, o narrador fecha as cortinas e, com tamanho zelo e pudor, anuncia aquilo que deve ser guardado na esfera do privado, do interdito. E o amor entre eles é revestido de pureza e religiosidade, o "santo amor conjugal", como deveria ser a legítima união entre marido e mulher. Falar de sexo, em um romance voltado para mulheres e donzelas, era ainda um tabu, ou pelo menos era isso o que Alencar, afinado com a moral conservadora da sua época, queria preservar, uma vez que o público leitor, majoritariamente, era composto pelas mulheres. Logo, as cortinas são fechadas e assim se encerra o romance Senhora.

\section{Considerações finais}

Temos a representação de uma mulher forte, determinada, autônoma e que toma para si o poder de decisão para as suas vontades. Diante de sua posição feminina, desde muito cedo Aurélia teve de aprender a lidar com as adversidades que a vida foi lhe apresentando. Como era de praxe no casamento das mulheres da mesma classe so-

https://periodicos.unifap.br/index.php/letras

Macapá, v. 7, n. 4, 20 semestre, 2017 


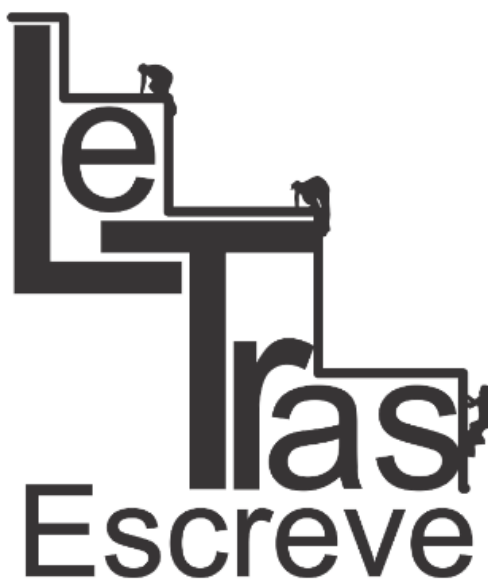

(ISSN 2238-8060)

cial, o negócio matrimonial era acordado somente entre homens. Todavia, no caso de Aurélia, é ela quem escolhe e define os termos do contrato, cabendo a seu tio e tutor Lemos - parente masculino mais próximo da personagem - entrar em cena apenas para mediar a finalização do acordo. Realizado o matrimônio, Aurélia ocupa uma posição social tida como masculina, que era a de domínio e de provimento do lar. Mas esse lugar, considerado impróprio para as moças, não poderia ser ocupado por uma mulher a não ser com algumas consequências: Aurélia começa a sofrer de fadiga, desmaios, crises "nervosas" e abalos emocionais. Seria o preço a se pagar para as mulheres que não seguiam sua "vocação natural", conforme quer mostrar o autor, reforçando a fragilidade feminina.

E, apesar de ultrapassar algumas fronteiras do permitido para as heroínas românticas do século XIX, Aurélia é também a incorporação dos estereótipos da mulher ideal. Possuidora de um caráter e de uma moral incorruptíveis, a personagem, tendo nascido e crescido em meio a uma família pertencente ao segmento popular e de poucos recursos, recebera uma educação digna de moça rica e apreendeu com isso os valores burgueses, como as "boas maneiras" e hábitos "decentes" condizentes à mulher honesta. E ela sabia do valor do casamento para a sua reputação, afinal, uma mulher sem a companhia de um homem dificilmente era vista com bons olhos pela sociedade. Em um sistema que legitima a subordinação feminina, o "final feliz" esperado para uma prosa do Romantismo não poderia ser diferente nessa narrativa, quando há a inversão de papeis entre marido e mulher, ou melhor dizendo, a realocação dos papeis sociais de gênero em seus devidos lugares.

Sendo assim, o romance Senhora é mais um aparato cultural que, levando em conta as especificidades históricas do contexto em

https://periodicos.unifap.br/index.php/letras

Macapá, v. 7, n. 4, 2ㅇ semestre, 2017 


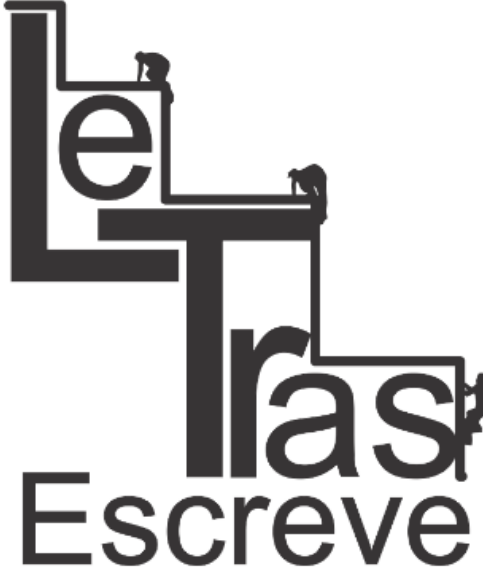

(ISSN 2238-8060)

que foi escrito, reafirma, por meio da ficção, a posição subalterna da mulher em uma sociedade estruturada pelo sistema patriarcal. No entanto, torna-se necessário fazer uma leitura não-homogeneizadora da sociedade brasileira daquela época, uma vez que a construção de imagens femininas idealizadas, elevando a mulher ao posto de santa e imaculada, semelhante à imagem da "Virgem Maria", não corresponde à realidade das mulheres, como bem analisa Ribeiro (2008), as mulheres literárias tão distantes das mulheres de carne e osso.

Cabe ressaltar ainda que o modelo da família nuclear burguesa, tão difundido na era vitoriana, está muito longe de retratar a realidade social do Brasil do Segundo Reinado. De acordo com as pesquisas de várias/os estudiosos/as como Fonseca (2015) e Soihet (2015), que vão lançar um outro olhar sobre as dinâmicas familiares do período, é possível constatar que o modelo vitoriano, de fato, não atingiu a maioria da população brasileira, sobretudo as famílias de classes subalternas. Diferentemente da família nuclear instituída pela burguesia, registros históricos mostram que a organização familiar era composta por uma multiplicidade de formas: mulheres chefes de família, mulheres amancebadas, mulheres trabalhadoras que proviam o lar, mulheres que abandonavam o companheiro/esposo para viver com outro ou que eram abandonadas, filhos/as sendo criados/as por várias pessoas, sendo elas de laços consanguíneos ou não.

Mas não se deve negar a enorme influência que o romantismo exerceu sobre a ideia de amor e casamento no ocidente, atravessando os períodos subsequentes da história e que repercute inclusive nos dias atuais, apesar de outras configurações familiares e modos de viver os relacionamentos, distante do modelo da família tradicional tão propagado no século XIX.

https://periodicos.unifap.br/index.php/letras

Macapá, v. 7, n. 4, 20 semestre, 2017 


\section{Referências}

ALENCAR, José de. Senhora. 2. ed. São Paulo: M. Claret, 2010. (Coleção A obra-prima de cada autor).

BOCAYUVA, Helena. Sexualidade e gênero no imaginário brasileiro: metáforas do biopoder. Rio de Janeiro: Revan, 2007.

BOSI, Alfredo. História concisa da literatura brasileira. 43. ed. São Paulo: Cultrix, 2006.

FONSECA, Cláudia. Ser mulher, mãe e pobre. In: DEL PRIORE, Mary; PINSKY, Carla Bassanezi (Orgs.). História das mulheres no Brasil. 10. ed. São Paulo: Contexto, 2015. p. 510-553.

FOUCAULT, Michel. História da sexualidade: a vontade de saber. 19. ed. Rio de Janeiro: Graal, 2007. v. 1.

GONÇALVES, Andréa Lisly. História \& gênero. Belo Horizonte: Autêntica, 2006.

INCAO, Maria Ângela. d'. Mulher e família burguesa. In: DEL PRIORE, Mary; PINSKY, Carla Bassanezi (Orgs.). História das mulheres no Brasil. 10. ed. São Paulo: Contexto, 2015. p. 223-240.

LINHARES, Juliana. Marcela Temer: bela, recatada e 'do lar'. Revista (ISSN 2238-8060) Veja, São Paulo, 18 abr. 2016.

MISKOLCI, Richard. O desejo da nação: masculinidade e branquitude no Brasil de fins de XIX. São Paulo: Annablume, 2013. (Coleção Queer).

RAGO, Margareth. Do cabaré ao lar: a utopia da cidade disciplinar: Brasil 1890-1930. 3. ed. Rio de Janeiro: Paz e Terra, 1997.

RIBEIRO, Luis Filipe. Mulheres de papel: um estudo do imaginário em José de Alencar e Machado de Assis. 2. ed. Rio de Janeiro: Forense Universitária; Fundação Biblioteca Nacional, 2008.

SOIHET, Rachel. Mulheres pobres e violência no Brasil urbano. In: DEL 
PRIORE, Mary; PINSKY, Carla Bassanezi (Orgs.). História das mulheres

no Brasil. 10. ed. São Paulo: Contexto, 2015. p. 362-400.

Recebido em 06/03/2017

Aceito em 08/06/2017

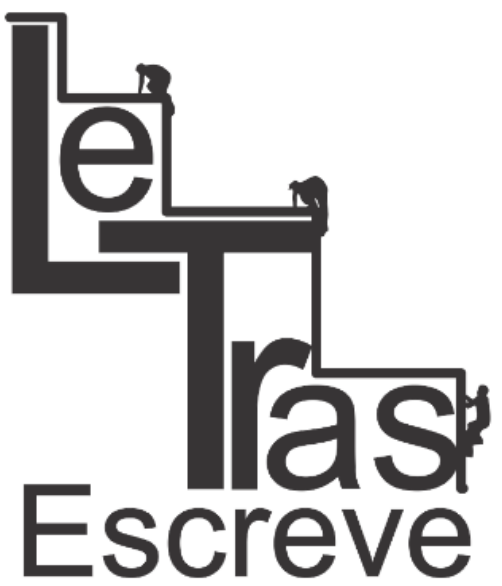

(ISSN 2238-8060) 